\title{
Effect of dietary vicine and vitamin $E$ supplementation on the productive performance of growing and laying chickens
}

\author{
BY DAVID S. MUDUULI, RONALD R. MARQUARDT \\ AND WILHELM GUENTER \\ Department of Animal Science, University of Manitoba, Winnipeg, \\ Manitoba R3T 2N2 Canada
}

(Received 26 February 1981 - Accepted 22 May 1981)

\begin{abstract}
1. Experiments were conducted to study the effects of dietary vicine (2, 6-diamino-4, 5 dihydroxy pyrimidine-5 ( $\beta$-D-glucopyranoside)) and supplemental vitamin $E$ on the performance of laying hens and growing chicks.

2. Chicks fed on diets that contained vicine had similar growth rates but slightly higher levels of spontaneous haemolysis of erythrocytes than birds fed on a control diet.

3. Vicine when fed to laying hens had a very dramatic effect. It depressed food consumption, egg weight, fertility and hatchability of eggs, packed cell volume and erythrocyte haemoglobin levels and led to increased liver weights, liver glutathione levels, liver and plasma lipid levels, plasma lipid peroxide levels and erythrocyte haemolysis in vitro. Liver protein and plasma vitamin E:lipid levels were not altered. Vitamin E supplementation slightly increased egg weights, markedly improved fertility and hatchability of eggs and lowered liver weights and lipid levels but did not affect the other factors examined.

4. It is concluded that vicine which was isolated from faba beans (Vicia faba L.) has a marked influence on the metabolism of the laying hen and only a slight effect on the growing chick. Vicine or its metabolites or both cause peroxidation of cellular components which result in abnormal lipid transport or synthesis or both, increased fragility of erythrocytes, and reduced fertility. These effects are overcome to varying extents by supplemental vitamin E.
\end{abstract}

Faba beans contain thermolabile and thermostable antinutritional factors. The thermolabile factors consist of several types of tannins (exclusively located in the testa), trypsin, chymotrypsin or general protease or both, and amylase inhibitors (equally distributed between the hull and cotyledon), and the lectins which are only found in the cotyledon (Marquardt et al. 1975, 1977; Cansfield et al. 1980). The thermostable factors are mainly associated with the protein fraction of the bean and consist mainly of pyrimidines and pyrimidine glucosides of which vicine and convicine (mainly located in the cotyledon) have been isolated (Mager et al. 1965; Mager et al. 1969; Campbell et al. 1980; Olaboro, Campbell et al. 1981; Olaboro, Marquardt et al. 1981). L-3,4-dihydroxyphenylalanine (L-DOPA) and its glucoside, located mainly in the green pod with smaller quantities in the testa of the bean (Longo et al. 1974) are also heat-resistant, but individually they do not seem to be detrimental to chicken performance (Olaboro, Campbell et al. 1981; Olaboro, Marquardt et al. 1981).

Dietary vicine and convicine have been shown to lower egg and yolk weights and, to a minor extent, the egg production rate (Olaboro, Campbell et al. 1981; Olaboro, Marquardt et al. 1981; Muduuli, 1980; Muduuli et al. 1981. In addition, laying birds fed vicine had fewer developing ova, an altered yolk shape and very fragile yolk membrane with increased incidence of blood spots (Muduuli et al. 1981). These birds had heavier livers and elevated levels of plasma lipid and lipid peroxides, liver lipid peroxides and glutathione (GSH), and erythrocyte haemolysis in vitro and depressed plasma vitamin $\mathrm{E}$ :lipid levels; however, liver and plasma protein levels were not affected by dietary vicine. Vicine and convicine are also suspected in the aetiology of favism (Mager et al. 1969). 
The biological effects of vicine and convicine are believed to be mediated through their aglycones, divicine and isouramil (Mager et al. 1965), although vicine, but not divicine, has been shown to inhibit the activity of glucose-6-phosphate dehydrogenase (EC 1.1 1. 1.49; G-6-PD) in vitro (Lin \& Ling, 1962 b). The aglycones are strong reducing compounds and rapidly autoxidize in the presence of oxygen but not carbon dioxide or nitrogen; the rate increasing with the increase in $\mathrm{pH}$ of the medium (Bendich \& Clements, 1953). These aglycones have been shown in vitro to lower erythrocyte GSH and ATP (Mager et al. 1965) and to form complexes with GSH (Lin, 1963). In vivo they also lowered GSH, increased potassium ion losses and increased lipid peroxidation which consequently promoted haemolysis (Flohe et al. 1971) of normal or G-6-PD deficient human erythrocytes or both. Flohe et al. (1971) suggested that the effect of the aglycones on human erythrocytes could be explained on the basis of free radical production. There are no reports on the ability of certain antioxidants (vitamin E) to overcome the effects of vicine. Research was therefore carried out to establish the extent to which vitamin $\mathrm{E}$ is able to counteract the adverse effects of dietary vicine in the laying hen. Additional research was also carried out to examine the effects that vicine has on certain biological criteria in the laying hen and growing chick.

\section{METHODS}

\section{Preparation of crude vicine}

Crude vicine was prepared using the procedure of Muduuli (1980) which is a modification of that reported by Olaboro, Marquardt et al. (1981). Chemical analysis using the procedures of Higazi \& Read (1974) or Collier (1976) demonstrated that this preparation contained $900 \mathrm{~g}$ vicine reactive material (i.e. vicine plus convicine) $/ \mathrm{kg}$.

\section{Laying hen experiments}

Egg size depression was determined according to the procedure of Olaboro, Campbell et al. (1981). In Expt 1, sixty mature Shaver-288 layers initially 26 weeks of age were individually caged and had free access to water. In order to establish normal egg weights and production rates, all birds were fed on a basal diet ad lib. for $20 \mathrm{~d}$ (control period). During the latter part of the control period, birds were allocated to one of three treatment groups such that the average egg weights of the groups were similar. The control period was followed by a $14 \mathrm{~d}$ test period in which birds in group 1 were continued on the basal diet ad lib., group 3 was given, ad lib., the basal diet containing $10 \mathrm{~g}$ vicine $/ \mathrm{kg}$, and group 2 was fed on the basal diet at a level approximating to the intake of birds in group 3 . Food intake in group 2 was adjusted every second day to the level consumed by birds in group 3 during the previous $2 \mathrm{~d}$ period. The failure to obtain equal feed intake in the two groups may be attributed to the progressively decreasing intakes of food in group 3 during the initial phases of the experiment. Eggs were collected during days 3-10 of the control period and days 5-14 of the test period and weighed. Food consumption represents average values for each period. On day 10 of the test period each bird was inseminated with $0.05 \mathrm{ml}$ fresh semen pooled from twelve males. The semen was deposited $15 \mathrm{~mm}$ into the oviduct and eggs were collected on two consecutive days, starting on the second day after insemination. The eggs were incubated in a Robbins incubator, at the University of Manitoba hatchery, on the second day of collection.

The basal diet was formulated to meet (US) National Research Council (1971) requirements, except for energy density which was slightly low. It consisted of $(\mathrm{g} / \mathrm{kg}): 690$ barley, 182.5 soya-bean meal, 17.5 tallow, 10.0 dehydrated lucerne (Medicago sativa), 42.5 calcium carbonate, $17 \cdot 5$ dicalcium phosphate, 20 oyster shell, 5 grit, 15 vitamin and mineral mix. The composition of the vitamin-mineral supplement has been described (Campbell et al. 
1980). The proximate analysis of the diet was $(\mathrm{g} / \mathrm{kg})$ : protein (nitrogen $\times 6.25) 170$, diethyl ether extract 50, acid-detergent fibre 69, metabolizable energy value (calculated) $10.8 \mathrm{MJ}$.

The procedure in Expt 2 was similar to that in Expt 1. Thirty Shaver-288 hens initially 26 weeks of age were randomized among three dietary treatments. Group 1 birds received the basal diet (Expt. 1), those of group 2 received the basal diet containing $12 \mathrm{~g}$ crude vicine $/ \mathrm{kg}$, and the third group received the same diet as group 2, but supplemented with ten times $(50 \mathrm{mg} / \mathrm{kg}$ food) more vitamin $\mathrm{E}$ ( $\alpha$-tocopherol); this level was raised to $200 \mathrm{mg} / \mathrm{kg}$ food after $6 \mathrm{~d}$ when it was observed that the egg weight in this group was declining. Birds were individually caged and fed $a d$ lib. The birds were inseminated on day 8 and eggs collected during days 10-14 of the experiment were incubated and hatched. Egg weights were obtained for the control period (the last $4 \mathrm{~d}$ before being placed on the test diets) and days $10-14$ of the test period.

Blood samples were obtained on day 14 of the test period from birds that had been starved for $12 \mathrm{~h}$. Packed cell volume values were determined on blood freshly drawn from the wing vein into heparin-coated capillary tubes. Blood $(10 \mathrm{ml})$ for the other analyses was obtained by heart puncture and was collected in a saline solution ( $9 \mathrm{~g}$ sodium chloride/l) containing EDTA $(20 \mathrm{~g} / \mathrm{l})$ and was separated into erythrocytes and plasma by centrifugation. Erythrocytes were washed with saline solution and used immediately. Birds were killed by exsanguination on day 14 and livers were excized, separated from the gall bladder, wiped between paper towels, frozen in liquid $\mathrm{N}_{2}$ in preweighed polyethyelene bags and weighed.

Plasma total lipid content was determined according to Heald \& Badman (1963). Lyophilized liver samples were analyzed for lipids by the method of Reshef et al. (1976). Plasma lipid peroxides were determined by the thiobarbaturic acid method of Asakawa \& Matsushita (1979), plasma vitamin E by the method of Bunnell (1967) and GSH levels by the method of Beutler et al. (1963). Assays for rates of spontaneous in vitro haemolysis of freshly-prepared erythrocytes were as outlined by Draper \& Csallany (1969). Haemoglobin was determined using the cyanmethaemoglobin method (Sigma Chemical Co., 1978). Liver protein was determined by the method of Lowry et al. (1951).

\section{Chick experiment}

In Expt 3, twenty-eight $7 \mathrm{~d}$ broiler chicks weighing $63-65 \mathrm{~g}$ were randomized among four dietary treatments. The birds were fed ad lib. a starter diet containing $0,2 \cdot 5,10$ or $20 \mathrm{~g}$ crude vicine $/ \mathrm{kg}$ for 2 weeks. The diet which was formulated to meet (US) National Research Council (1971) requirements consisted of $(\mathrm{g} / \mathrm{kg}): 626$ wheat, 252 soya-bean meal, 40 fish meal, 40 soya-bean oil, 14 calcium phosphate, 13 calcium carbonate, 15 vitamin and mineral mix. The composition of the vitamin-mineral supplement has been described (Marquardt $\&$ Ward, 1979). The proximate analysis of the diet was $(\mathrm{g} / \mathrm{kg}):$ protein (nitrogen $\times 6 \cdot 25)$ 218 , diethyl ether extract 46 , acid-detergent fibre 44 , calcium 10 , total phosphorus $8 \cdot 2$, metabolizable energy (calculated) $12.5 \mathrm{MJ}$. The birds were kept in temperature-controlled battery brooders (Petersime) equipped with continuous lighting.

At the end of the 2-week experimental period, the birds were starved for $12 \mathrm{~h}$ and weighed and blood samples were collected and analysed for the extent of spontaneous haemolysis as described previously.

\section{Other analyses}

Proximate analyses were determined by methods according to the Association of Official Agricultural Chemists (1970). Statistical analysis, including one-way analysis of variance, comparison of means using Student-Newman-Keul's test and the computation of $\chi^{2}$ were determined according to the methods given by Snedecor \& Cochran (1967). 


\section{RESULTS AND DISCUSSION}

Food consumption in Expt 1 was depressed $(16 \%, P<0.05)$ when vicine was aded to the basal diet (Table 1) and was slightly lowered $(5 \%, P<0.05)$ in the vicine-fed birds as compared to those given restricted intakes of the basal diet. Egg size in the restrictedfood-intake group in contrast was not depressed $(P>0.05)$ relative to those fed the basal diet $a d$ lib. but was depressed $(14 \%, P<0.001)$ in the vicine-fed birds as compared to the other two groups. These results would suggest that food intake was not directly responsible for reduced egg size. These conclusions are supported by the results from a previous study (Olaboro, Marquardt et al. 1981) which demonstrated that egg size but not food consumption was depressed when birds were fed on vicine containing diets. Hatchability of eggs which was different among groups $(P<0.025)$, was considerably lower $(33 \%)$ in hens fed on vicine as compared to those fed restricted $(84 \%)$ or ad lib. $(90 \%)$ intakes of the basal diet.

The results of the second experiment (Table 2) demonstrate that food consumption $(P<0.01)$ and egg weights $(P<0.001)$ were lower in the vicine-fed birds as compared to those given the basal diet. Although egg weights were depressed in both vicine-fed groups (10 and $8 \%, P<0.001$ ) as compared to the control groups, those in the vitaminE-supplemented groups were affected slightly less $(2 \%, P>0.05)$ than those fed on vicine alone. A marked depression in the fertility $(P<0.005)$ and hatchability of total eggs and fertile eggs $(P<0.01)$ occurred when $12 \mathrm{~g}$ vicine $/ \mathrm{kg}$ was added to the diet. These effects were greater for fertility ( $59 \%$ decrease) and percentage hatchability (69\% decrease) of all eggs than for percentage hatchability of fertile eggs $(36 \%$ decrease) which indicates that vicine affected the early stages of embryonic development. The addition of excess vitamin $E$ to the vicine-containing diet markedly improved the fertility and hatchability of eggs $(P<0.01$ and $P<0.005$ respectively). These results would suggest that vicine interferes with or affects vitamin $E$ utilization in the laying hen and are analogous to those of Adamstone (1931) who reported that Vitamin E deficiency markedly reduced the hatchability of eggs. He also reported that peak embryonic mortality in eggs from hens fed on vitamin E-deficient diets occurred during early embryonic development.

Dietary vicine also affected the liver as it increased $(P<0.05)$ liver weights $(14 \%)$ and lipid levels $(18 \%)$. Supplemental additions of dietary vitamin E reduced lipid values to control levels $(P<0.05)$. In contrast, neither vicine nor excess vitamin $\mathrm{E}$ affected $(P>0.05)$ liver protein concentrations. A comparison of blood and plasma characteristics demonstrated that lipids $(P<0.01)$, lipid peroxides $(P<0.01)$, extent of spontaneous haemolysis of erythrocytes $(P<0.001)$ and GSH $(P<0.001)$ were higher and packed cell volume $(P<0.001)$ and haemoglobin $(P<0.05)$ levels were lower in the vicine-fed birds (groups 2 and 3 ) as compared to those fed on the basal diet. Vitamin E, at relatively high levels did not reduce $(P>0.05)$ lipids and lipid peroxides in plasma or protect erythrocytes against vicine. Addition of glucose to the incubation medium reduced $(P<0.05)$ in vitro haemolysis in all groups, but the effect was greater $(P<0.05)$ in the vicine-fed groups than the control group. Thus a lack of glucose or its reducing metabolites may in part account for the haemolysis induced by vicine. Over all, the results presented in this study are consistent with the more limited results reported in previous studies (Campbell et al. 1980; Muduuli et al. 1981; Olaboro, Campbell et al. 1981; Olaboro, Marquardt et al. 1981).

The results with the growing chick (Table 3) demonstrate that growth is not affected $(P>0.05)$ by the addition of relatively high levels of vicine to the diet and that it induces only a slight increase $(P<0.05)$ in the extent of spontaneous haemolysis of erythrocytes which appears to be independent of the vicine content of the diet. In studies with rats, Collier et al. (1978) reported that an equivalent of approximately $10 \mathrm{~g}$ vicine $/ \mathrm{kg}$ in the diet $(900 \mathrm{~g}$ 
Table 1. Expt 1. Laying hen performance and hatchability of eggs as affected by dietary vicine

(Mean values for twenty birds in each group)

\begin{tabular}{|c|c|c|c|c|}
\hline & \multicolumn{4}{|c|}{ Basal diet* } \\
\hline & ad lib. & $\begin{array}{l}\text { Restricted } \\
\text { intake }\end{array}$ & $\begin{array}{c}\text { Containing } \\
10 \mathrm{~g} \\
\text { vicine } / \mathrm{kg}\end{array}$ & $\mathbf{S E}$ \\
\hline \multicolumn{5}{|l|}{ Food consumption: } \\
\hline Control period ( $\mathrm{g} /$ bird per $\mathrm{d}$ ) & 121 & 120 & 121 & 2 \\
\hline Test period $\dagger$ & $98^{\mathrm{c}}$ & $82^{b}$ & $77^{8}$ & 2 \\
\hline Body-wt (g) $\dagger$ & 91 & 89 & 90 & $\overline{1}$ \\
\hline Egg wt $(\mathrm{g})$ & $56^{\mathrm{B}}$ & $56^{\mathrm{B}}$ & $48^{\mathrm{A}}$ & $i$ \\
\hline Hatchability of eggs $(\%) \ddagger$ & $90(41)$ & $84(37)$ & $33(30)$ & \\
\hline
\end{tabular}

a, b, c, or A, B. Values within the same horizontal row with different superscript letters were statistically significantly different at $P<0.05$ or $P<0.001$, respectively.

* For details, see p. 54.

$\dagger$ Test period as a percentage of control period.

$\ddagger$ No. of eggs set are given in parentheses. Eggs were hatched together, therefore only a $\chi^{2}$ test was carried out. Hatchability (\% of total eggs) differed among the treatments $(P<0.025)$.

faba beans $/ \mathrm{kg}$ ) did not impair growth, food intake or liver function or decrease blood haemoglobin levels in weanling rats as compared to control animals.

The ability of vitamin $\mathrm{E}$ to alleviate the vicine-induced depression in fertility and hatchability of eggs is consistent with the proposal that vicine initiates the production of free radicals (Flohe et al. 1971) and the role of vitamin $\mathrm{E}$ as a scavenger of free radicals (Scott, 1978). The results in this study are also in agreement with those reported by Corash et al. (1980) with humans. They reported a reduced level of chronic haemolysis during high-dose vitamin $\mathrm{E}$ administration to G-6-PD deficient individuals; individuals who also develop the haemolytic disease, favism, following the consumption of faba beans. Mager et al. (1969) has presented evidence which suggests that the active favism-inducing agents are the aglycones of vicine and convicine. It may therefore be concluded that these compounds are not only responsible for favism in humans but also for the adverse effects in the laying hen and that they are overcome to a certain extent by the free-radical scavenger, vitamin E. It is conceivable that a deficiency of other nutrients such as selenium or riboflavin which are cofactors for enzymes involved in free radical metabolism (Scott, 1978) would also modify vicine-induced toxicity. Recent studies by D'Aquino et al. (1979) support this proposal. They reported a dramatic in vitro increase in erythrocyte GSH concentration in the presence of isouramil (the aglycone of convicine) when erythrocytes were obtained from riboflavin-deprived rats but not control rats.

The results from the present study and those of previous workers with rats (Collier et al. 1978; Lin \& Ling, 1962a) suggest that chicks and rats are rather insensitive to the effects of vicine whereas the laying hen is highly sensitive to its effects. The reason for this difference has not been established but may be related to the type of metabolism occurring in the different types of animals. In the hen for example, egg production requires that the animal synthesize considerable quantities of fat and protein whereas in the growing chick the relative level of fat synthesis is much lower. It is conceivable as discussed previously, that vicine or its hydrolytic product divicine, places additional stress or demand on the free-radical scavenging system (Flohe et al. 1971; Scott, 1978) for available NADPH in a manner similar 
Table 2. Expt 2. Laying hen performance, fertility and hatchability of eggs and plasma and liver characteristics as affected by dietary vicine with or without vitamin $E$ supplementation

(Mean values for ten birds in each group)

\begin{tabular}{|c|c|c|c|c|}
\hline & \multicolumn{4}{|c|}{ Basal diet* } \\
\hline & Alone & $\begin{array}{l}\text { Containing } \\
\text { vicine }\end{array}$ & $\begin{array}{c}\text { Containing } \\
\text { vicine } \\
\text { and added } \\
\text { vitamin } E\end{array}$ & SE \\
\hline \multicolumn{5}{|l|}{ Bird performance: } \\
\hline \multirow{2}{*}{$\begin{aligned} & \text { Food consumption: } \text { g/bird per } \mathrm{d} \\
& \mathrm{g} / \mathrm{kg} \text { body-wt }\end{aligned}$} & $107^{\mathrm{s}}$ & $85^{\mathrm{A}}$ & $87^{\wedge}$ & 4 \\
\hline & $30^{\mathrm{B}}$ & $25^{\mathrm{A}}$ & $25^{\mathrm{A}}$ & 1 \\
\hline \multicolumn{5}{|l|}{ Egg weight: } \\
\hline Control period $(\mathrm{g})$ & 54 & 53 & 54 & 1 \\
\hline Test period $\dagger$ & $104^{\mathrm{B}}$ & $94^{A}$ & $96^{4}$ & 1 \\
\hline \multicolumn{5}{|l|}{ Fertility and hatchability of eggs $s_{+}^{+}$: } \\
\hline No. of eggs set & 25 & 22 & 22 & \\
\hline Fertility of eggs $(\%)$ & 100 & 41 & 82 & \\
\hline Hatchability of total eggs $(\%)$ & 92 & 23 & 68 & \\
\hline Hatchability of fertile eggs $(\%)$ & 92 & 56 & 83 & \\
\hline \multicolumn{5}{|l|}{ Liver characteristics: } \\
\hline Liver wt $(\%$ body-wt $)$ & $0 \cdot 80^{\circ}$ & $0.91^{b}$ & $0 \cdot 84^{\text {ab }}$ & 0.02 \\
\hline Lipid level $(\%$ liver $w t)$ & $6 \cdot 0^{4}$ & $7 \cdot 1^{\mathrm{b}}$ & $6 \cdot 3^{\mathrm{a}}$ & $0 \cdot 3$ \\
\hline Protein (g/g liver) & $0 \cdot 20$ & $0 \cdot 21$ & $0 \cdot 21$ & $0 \cdot 01$ \\
\hline \multicolumn{5}{|l|}{ Plasma and blood characteristics: } \\
\hline Lipids ( $\mathrm{mg} / \mathrm{ml})$ & $7 \cdot 7^{\mathrm{a}}$ & $13.3^{\mathrm{b}}$ & $12 \cdot 9^{b}$ & $1 \cdot 3$ \\
\hline Vitamin $\mathrm{E}:$ lipids $\left(\mathrm{mg} \times 10^{4} / \mathrm{mg}\right)$ & $4 \cdot 8^{\mathrm{A}}$ & $4 \cdot 6^{\mathrm{A}}$ & $9 \cdot 2^{\mathrm{B}}$ & $0 \cdot 7$ \\
\hline Lipid peroxides (nmol MDA $/ \mathrm{ml}$ )§ & $0 \cdot 9^{\mathrm{A}}$ & $1 \cdot 6^{\mathrm{H}}$ & $1 \cdot 6^{\mathrm{B}}$ & $0 \cdot 1$ \\
\hline Packed cell volume & $0 \cdot 31^{\mathrm{B}}$ & $0 \cdot 22^{A}$ & $0 \cdot 23^{A}$ & $0 \cdot 01$ \\
\hline Spontaneous haemolysis $(\%)$ & $22^{\mathrm{A}}$ & $64^{\mathrm{B}}$ & $54^{\mathrm{B}}$ & 5 \\
\hline Haemoglobin ( $\mathrm{mg} / \mathrm{ml}$ haemolysate) & $25 \cdot 3^{\mathrm{b}}$ & $22 \cdot 4^{\mathrm{a}}$ & $22 \cdot 8^{\mathrm{a}}$ & $0 \cdot 9$ \\
\hline Glutathione $(\mu \mathrm{mol} / \mathrm{ml})$ & $0.51^{\mathrm{A}}$ & $0 \cdot 74^{\mathrm{B}}$ & $0.65^{\mathrm{B}}$ & $0 \cdot 02$ \\
\hline
\end{tabular}

a. $b$ or A, B. Values within the same horizontal row with different superscripts were statistically significantly different at $P<0.05$ or $P<0.001$, respectively except for food consumption and lipid peroxide levels which were different at $P<0.01$.

* For details, see p. 54.

+ Test period as a percentage of control period.

+ Eggs were hatched together. therefore a $\chi^{2}$ test was carried out; differences in hatchability and fertility were statistically significant $(P<0.01$ and $P<0.005$ respectively).

$\S$ MDA, malondialdehyde.

Table 3. Expt 3. Weight gain (14d) and spontaneous haemolysis in broiler chicks fed on a diet containing various levels of vicine

(Mean values for seven birds in each group)

\begin{tabular}{ccc}
\hline $\begin{array}{c}\text { Dietary level } \\
\text { of crude vicine } \\
(\mathrm{g} / \mathrm{kg})\end{array}$ & $\begin{array}{c}\text { Body-wt } \\
\text { gain }(\mathrm{g})\end{array}$ & $\begin{array}{c}\text { Spontaneous } \\
\text { haemolysis }(\%)\end{array}$ \\
\hline 0 & 112 & $6 \cdot 4^{\mathrm{a}}$ \\
$2 \cdot 5$ & 112 & $9 \cdot 9^{\mathrm{b}}$ \\
$9 \cdot 4^{\mathrm{b}}$ \\
$10 \cdot 0$ & 111 & $9 \cdot 2^{\mathrm{b}}$ \\
$20 \cdot 0$ & 103 & $1 \cdot 0$ \\
\hline
\end{tabular}

a, b. Values within the same column with different superscripts were statistically significantly different $(P<0.05)$. 
to that which occurs in favism-susceptible humans (Mager et al. 1969). As a result NADPH, which is required for both fat synthesis and for maintaining plasma GSH in its reduced form (Scott, 1978) becomes limiting. The net effect would be a reduced extent of protection against free radicals which would result in increased fragility of cell wall membranes including those of erythrocytes and yolks or a reduced level of fat synthesis or both. The reduced yolk size together with an increase in plasma lipids suggest that vicine or its hydrolytic products may interfere with lipid transport perhaps by modifying the membranes involved in fat transport.

In conclusion, the present study provides new information on the effects of vicine on the animal and suggests that the laying hen can serve as a model animal for studying the mode of action of the favism-inducing toxins (vicine, convicine or their aglycones or both). The results with the laying hen demonstrate that vicine has pronounced effects with regard to fertility and hatchability of eggs, packed cell volume levels, extent of spontaneous haemolysis of erythrocytes and plasma lipid levels and that these effects can be modified to varying extents by high levels of vitamin $\mathrm{E}$.

This investigation was supported by grants from Agriculture and Food Products Market Development Assistance Program, Government of Canada and from the Manitoba Department of Agriculture. A CIDA graduate student assistantship was held by one of the authors (D.S.M.). The authors with to thank Messrs H. Muc and S. Antonation for technical assistance.

\section{REFERENCES}

Adamstone, F. B. (1931). J. Morph. 52, 47.

Asakawa, T. \& Matsushita, S. (1979). Lipids 14, 401.

Association of Official Agricultural Chemists. (1970). Official Methods of Analysis of the Association of Official Agricultural Chemists, 11 th ed. Washington, DC: Association of Official Agricultural Chemists.

Bendich, A. \& Clements, G. C. (1953). Biochim. biophys. Acta 12, 462.

Beutler, E., Duran, O. \& Kelly, B. M. (1963). J. Lab. clin. Med. 61, 882.

Bunnell, R. H. (1967). In The Vitamins, vol. 6, p. 298 [P. Gyorgy and W. N. Pearson, editors]. New York: Academic Press.

Campbell, L. D., Olaboro, G., Marquardt, R. R. \& Waddell, D. (1980). Can. J. Anim. Sci. 60, 395.

Cansfield, P. E., Marquardt, R. R. \& Campbell, L. D. (1980). J. Sci. Fd Agric. 31, 802.

Collier, H. B. (1976). J. Inst. Can. Sci. Techn. Aliment. 9, 155.

Collier, H. B., Aherne, F. X. \& Kennelly, J. J. (1978). Can. J. Anim. Sci. 58, 531.

Corash. L., Speilberg. S., Bartsocas, C., Boxer, L., Steinberz, R., Sheetz, M., Egan, M., Schlessleman, J. \& Shulman, J. D. (1980). New Engl. J. Med. 303, 416.

D'Aquino, M., Gaetani, S. \& Spadoni, M. A. (1979). Nutr. Rep. int. 20, 1.

Draper, H. H. \& Csallany, A. S. (1969). J. Nutr. 98, 390.

Flohe, L., Neibch, G. \& Reiber, H. (1971). Z. Klin. Chem. Klin. Biochem. 9, 431.

Heald, P. J. \& Badman, H. G. (1963). Biochim. biophys. Acta 70, 381.

Higazi, M. I. \& Read, W. W. C. (1974). J. Agric. Fd Chem. 22, 570.

Lin. J-Y. (1963). J. Formosan med. Ass. 62, 777.

Lin, J-Y. \& Ling, K. H. (1962a). J. Formosan med. Ass. 61, 484.

Lin, J-Y. \& Ling, K. H. (1962b). J. Formosan med. Ass. 61, 579.

Longo, R., Castellani, A., Sberze, P. \& Tibella, M. (1974). Phytochemistry 13, 167.

Lowry, O. H., Rosebrough, N. J., Farr, A. L. \& Randall, R. J. (1951). J. biol. Chem. 193, 265.

Mager, J., Glaser, G., Razin, A., Izak, G., Bien, S. \& Noam, M. (1965). Biochem. Biophys. Res. Comm. $20,235$.

Mager, J., Razin, A.\& Hershko, A. (1969). In Toxic Constituents of Plant Foodstuffs, p. 293 [E. D. Liener, editor]. New York and London: Academic Press.

Marquardt, R. R., McKirdy, J. A., Ward, T. \& Campbell, L. D. (1975). Can. J. Anim. Sci. 55, 421.

Marquardt, R. R. \& Ward, A. T. (1979). Can. J. Anim. Sci. 59, 781.

Marquardt, R. R., Ward, A. T., Campbell, L. D. \& Cansfield, P. E. (1977). J. Nutr. 107, 1313.

Muduuli, D. S. (1980). Quantitative isolation of vicine from faba bean protein concentrate and the involvement of free radicals in the biophysiochemical effects of dietary vicine in chickens. PhD Thesis, University of Manitoba, Winnipeg.

Muduuli. D. S., Marquardt, R. R. \& Guenter, W. (1981). Can. J. Anim. Sci. (In the Press). 
National Research Council (1971). Nutrient Requirements of Domestic Animals no. 1, Nutrient Requirements of Poultry. Washington, DC: National Academy of Sciences.

Olaboro, G., Campbell, L. D. \& Marquardt, R. R. (1981). Can. J. Anim. Sci. (In the Press).

Olaboro, G., Marquardt, R. R. \& Campbell, L. D. (1981). J. Sci. Fd Agric. (In the Press).

Reshef, G., Gestetner, B., Birk, Y. \& Bond, A. (1976). J. Sci. Fd Agric. 27, 63.

Scott, M. L. (1978). In Handbook of Lipid Research, vol. 3, p. 133 [H. F. de Luca, editor]. New York: Plenum Press.

Sigma Chemical Co. (1978). Sigma Tech. Bull. no. 190. St Louis, Missouri: Sigma Chemical Co.

Snedecor, G. W. \& Cochran, W. G. (1967). Statistical Methods, 6th ed. Ames, Iowa: Iowa State University Press. 